\title{
INSTYTUT PATRYSTYCZNY W TARNOWIE
}

Jedną z posoborowych prób reformy polskich studiów teologicznych była myśl ujęcia ich na wzór rzymski w formę instytutów. Ksiądz kard. Karol Wojtyła, będąc przewodniczącym Komisji Episkopatu d/s Nauki Katolickiej, czuł się za to szczególnie odpowiedzialny i zamierzal ją przeprowadzić najpierw w podległym sobie Papieskim Fakultecie Teologicznym w Krakowie, planując w należących do niego Wyższych Seminariach Duchownych utworzyć, stosownie do panujących w nich od lat tradycji naukowych, specjalistyczne instytuty: w Częstochowie Instytut Eklezjologiczno-Mariologiczny, w Katowicach Instytut Duszpasterski, w Kielcach Instytut Homiletyczny, a w Tarnowie Instytut Patrystyczny; nadzór administracyjno-naukowy pełniłby nad nimi dziekan krakowskiego Fakultetu Teologicznego, one zaś byłyby utrzymywane przez miejscowe diecezje. Do próby zrealizowania tej myśli Ksiądz Kardynał przekonał najpierw księdza biskupa Jerzego Ablewicza, ordynariusza w Tarnowie, gdzie jak mu zapewne było wiadomo, żywe były od lat tradycje patrystyczne. To z tej diecezji pochodził inicjator znanej serii patrystycznej „Pisma Ojców Kościoła” - J. Sajdak, stąd tłumacz pism katechetycznych św. Augustyna - ks. W. Budzik, stąd wielki popularyzator i tłumacz pism Ojców Kościoła - ks. J. Czuj, stąd wielki filolog i tłumacz wielu pism greckich autorów wczesnochrześcijańskich - T. Sinko, stąd działający wówczas w Tarnowie badacz i tłumacz wielu pism patrystycznych, w tym także syryjskich - ks. W. Kania, a w Warszawie na ATK twórca znanej serii „Pisma Starochrześcijańskich Pisarzy” - redemptorysta ks. E. Stanula, i stąd znany mu dobrze z Rzymu niewykorzystany dotąd pierwszy polski doktor nauk patrystycznych (1976) po Instytucie Patrystycznym „Augustinianum” ks. S. Longosz, który po powrocie pracował jako wikariusz przy bazylice katedralnej w Tarnowie. Ksiądz Biskup J. Ablewicz jesienią 1977 r. przedstawił ogólnie pomysł założenia Instytutu Patrystycznego w Tarnowie najpierw na jednej z konferencji profesorów Wyższego Seminarium Duchownego (=Instytutu Teologicznego), informując, że tego rodzaju agregowany do Fakultetu Teologicznego w Krakowie Instytut działałby na prawach papieskich z możliwością nadawania akademickich stopni licencjatu i doktoratu. Wybór kierunku patrys- 
tycznego jest podyktowany sytuacją dzisiejszego Kościoła, bardzo zbliżoną do sytuacji Kościoła starożytnego, oraz ogólną posoborową tendencją powrotu do źródeł i ożywienia nimi duchowości kapłanów. Obok więc aspektu ściśle naukowego miałby on profil duszpasterski. Ojców Kościoła należałoby więcej uwzględniać w nauczaniu teologii dogmatycznej i moralnej, w homiletyce, w katolickiej nauce społecznej, w egzegezie Pisma św. i ascetyce, oraz nauczyć kleryków, jak, gdzie i kiedy winni oni korzystać z nauki Ojców Kościoła. Propozycję tę profesorowie przyjęli na ogół krytycznie i bez entuzjazmu.

Ksiądz Biskup jednak dalej kontynuował realizację swego zamiaru. $\mathrm{Na}$ bezpośredniego organizatora przyszłego Instytutu powołał (ustnie) ks. S. Longosza, którego wprowadził w swoje plany i zlecił mu przygotowanie (po polsku i po łacinie) projektu statutów tego rodzaju Instytutu, z uwzględnieniem statutów krakowskiego Fakultetu Teologicznego i należącego doń Instytutu Liturgicznego, statutów analogicznych instytutów rzymskich na prawie papieskim, zwłaszcza Instytutu Patrystycznego „Augustinianum”, a przede wszystkim niedawno opublikowanego (31 X 1977) przez Kongregację d/s Wychowania Katolickiego przygotowanego do dyskusji projektu nowej Konstytucji Apostolskiej o kościelnych studiach akademickich (Notanda - Schema novae Constitutionis Apostolicae de studiis academicis ecclesiasticis et Ordinationum S. Congregationis pro Institutione Catholica); miał on także nawiązać kontakty z polskimi patrologami (był wówczas prezesem Sekcji Patrystycznej), którzy zechcieliby współpracować z powstającym Instytutem, zacząć gromadzić specjalistyczną bibliotekę patrystyczną przez sprowadzenie podstawowych serii (uzupełnić zdekompletowaną Patrologię Migne'a, sprowadzić Corpus Christianorum i Sources Chrétiennes) i czasopism („Augustinianum”, „Vigiliae Christianae”, „Vetera Christianorum”, „Rivista di Archeologia Cristiana” i inne) patrystycznych, oraz zorganizować w jednej z większych sal Wyższego Seminarium Duchownego lektorium patrystyczne (Patristicum); na to wszystko miał przyrzeczone poparcie Księdza Biskupa i obiecane pieniądze.

W niedługim czasie ks. Longosz przygotował pierwszy projekt statutów Instytutu, krótką historię Instytutu Filozoficzno-Teologicznego (WSD) w Tarnowie, listę profesorów (Collegium professorum), wykaz nauczanych dyscyplin oraz podzielony na poszczególne semestry wykaz przedmiotów obowiązkowych do licencjatu (Disciplinae docendae), a także zamówił odpowiednie serie i czasopisma patrystyczne oraz wyposażenie przyszłego lektorium. Pierwsza merytoryczna dyskusja nad projektem statutów Instytutu odbyła się w obecności księdza Biskupa 21 II 1978 r. podczas konferencji profesorów Seminarium Duchownego w Tarnowie ${ }^{1}$. Podczas dyskusji nad projektem zasugerowano m.in. podkreślenie w nim większej autonomiczności Instytutu wobec Fakul-

${ }^{1}$ Por. Księge protokótów z konferencji profesorów WSD w Tarnowie. Protokół z posiedzenia 21 II 1978 punkt 4, protokółował ks. T. Brzegowy. 
tetu Teologicznego oraz większe uwzględnienie w nim polskiego i tarnowskiego środowiska, a także większe uwypuklenie profilu duszpasterskiego. Ustalono, że Instytut będzie agregowany do Fakultetu Teologicznego. Dla szczegółowszego jednak dopracowania projektu statutów powołano za sugestią Księdza Biskupa specjalną komisję, w skład której weszli: ks. dr S. Longosz, ks. dr M. Bednarz, ks. dr hab. J. Dudziak, ks. dr E. Krężel, ks. dr hab. W. Kania, ks. dr K. Kupiec, ks. dr E. Łomnicki, ks. dr B. Margański i ks. dr A. Paciorek. Komisja ta zbierała się parę razy (po raz pierwszy już 28 II 1978 r.) w cotygodniowych odstępach i dopracowywała szczegółowo poszczególne części statutów, w czym brał również czynny udział ks. Biskup. Przygotowany zaś ostatecznie projekt statutów wraz $\mathrm{z}$ ustalonym wykazem profesorów i nauczanych dyscyplin, zatwierdzony przez Księdza Biskupa, miał być przekazany Kongregacji d/s Wychowania Katolickiego przez księdza kardynała Karola Wojtyłę w najbliższym czasie, sam Instytut natomiast, jeśli wszystkie sprawy zdąży się załatwić, miał rozpocząć swoją działalność w październiku 1979 roku.

Dla większego spopularyzowania myśli Ojców Kościoła w diecezji, ks. biskup Ablewicz jak i ks. Longosz podjęli szereg inicjatyw w tym kierunku. Najpierw Ksiądz Biskup przyjął do gmachu Wyższego Seminarium Duchownego największe po II wojnie światowej trzydniowe ogólnopolskie sympozjum z udziałem dwóch profesorów z rzymskiego Instytutu Patrystycznego (Vittorino Grossi, Thomas Špidlik), zorganizowane 19-21 X 1978 r. przez Sekcję Patrystyczną, Katedry Patrologii ATK i Międzywydziałowy Zakład Badań nad Antykiem Chrześcijańskim KUL, połączone z uroczystą wieczorną koncelebrą uczestników pod przewodnictwem ks. bpa J. Ablewicza w wypełnionej po brzegi bazylice katedralnej, który też wygłosił okolicznościową homilię ${ }^{2}$; miał je otworzyć ks. kardynał K. Wojtyła, ale przeszkodzony wyjazdem na konklawe przesłał tylko do jego uczestników list na ręce prezesa Sekcji Patrystycznej ${ }^{3}$. Ponadto w 1980 r. Ksiądz Biskup zorganizował dwukrotnie katechetyczne dni duszpasterskie dla wszystkich księży diecezji, najpierw na temat: Wychowanie dziecka w nauczaniu Ojców Kościoła, a następnie na temat Starożytnych symboli wiary, podczas których ks. W. Kania, ks. S. Longosz i ks. A. Paciorek wygłaszali patrystyczne konferencje. Podobnie ks. S. Longosz wygłaszał różnego rodzaju konferencje na temat Ojców Kościoła podczas organizowanych w różnych miejscach diecezji Tygodni Wiary, na spotkaniach $\mathrm{KIKu}$, na comiesięcznych spotkaniach Tarnowskiego Oddziału PTT i z okazji przypadających różnych rocznic patrystycznych (np. śmierci św. Bazylego, urodzin św. Benedykta) dla kleryków Seminarium ${ }^{4}$. Ponadto na początku

\footnotetext{
2 Por. ,Tarnowskie Studia Teologiczne” 8 (1981) 269-273.

${ }^{3}$ Por. tamże, s. 11 lub s. 13-14.

${ }^{4}$ Por. S. Longosz, Popularyzacja Ojców Kościola w latach 1979-1980 na terenie diecezji tarnowskiej, „Currenda” 131 (1981) 34-36.
} 
1979 r. ks. Longosz udał się ze specjalną rekomendacją Księdza Biskupa ${ }^{5}$ do Rzymu w poszukiwaniu książek dla biblioteki organizowanego Instytutu; wówczas to został również przyjęty przez papieża Jana Pawła II, od którego oprócz Apostolskiego Błogosławieństwa dla Instytutu, otrzymał milion lirów na książki.

Instytut według proponowanych statutów miał być agregowany do Papieskiego Fakultetu Teologicznego jako jego sekcja specjalizacji w nauce Ojców Kościoła; miał mieć charakter naukowo-pastoralny i znajdować się pod patronatem św. Jana Chryzostoma. Miał się jednak cieszyć swoimi przewidywanymi w przepisach prawami i współpracować z miejscowym Instytutem FilozoficznoTeologicznym (WSD). Jego celem miało być: I. zgłębianie nauki Ojców Kościoła, by z niego wynikało pełniejsze zrozumienie historii zbawienia i tajemnicy Chrystusa, pomocne w rozwiązywaniu problemów współczesnego życia chrześcijańskiego; 2. czerpanie z nauki Ojców Kościoła wzorców i korzyści duchowych dla współczesnego duszpasterstwa; 3 . dostarczenie profesorom możliwości wyjaśniania i tłumaczenia pism Ojców Kościoła; 4. pogłębienie przez duchownych wiedzy patrystycznej, umożliwiające im osiąganie licencjatu, a nawet doktoratu $\mathrm{z}$ tej dziedziny.

Do jego władz miały należeć: Wielki Kanclerz Fakultetu Teologicznego, dyrektor Instytutu, którym (zgodnie z życzeniem Księdza Biskupa) miał być miejscowy ks. bp ordynariusz, dziekan Fakultetu Teologicznego, prezes Insty-

${ }^{5}$ Por. rekomendację ks. bpa J. Ablewicza:

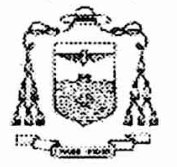

\section{BISKUP ORDYNARUUSZ TARNOWSKI}

33-100 TARNÓW, UL DZIERŻYŃSKIEGO 9, TEL. 25-01

Raccomandazione

Con la presente lettera autorizzo Don Dottore Stanislao Longosz, il professore dell'Istituto Teologico di Tarnów a prendere gli sforzi in ordine di completare la biblioteca dell'Istituto Patristico, che si sta organizzando a Tarnów, presso la Pontificia Facoltà Teologica di Cracovia.

Vorrei nello stesso tempo già in anticipo ringraziare per l'atteggiamento favorevole nella causa sopra presentata, concernente lo sviluppo degli studi patristici in Polonia.

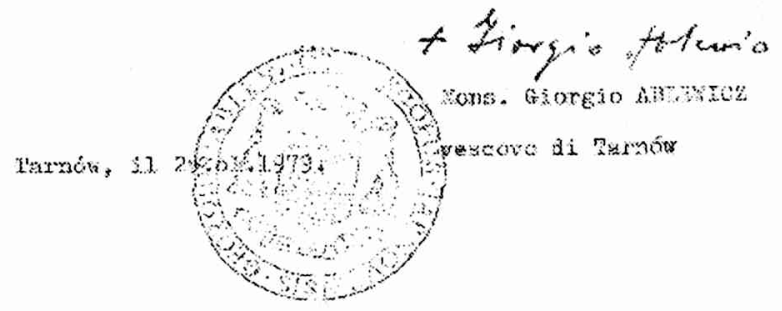


tutu Patrystycznego, jego sekretarz oraz Rada Akademicka, w skład której mieli wchodzić wybrani profesorowie Instytutu i rektor Instytutu Filozoficzno-Teologicznego. Stopnie zaś akademickie, uzyskiwane w Instytucie, miały być podpisywane przez Wielkiego Kanclerza, dyrektora Instytutu, dziekana Fakultetu Teologicznego oraz prezesa i sekretarza Instytutu.

Jeśli chodzi o przedmioty nauczane w Instytucie, to miały nimi być przede wszystkim te dyscypliny, które mogą przynieść jak największą korzyść duszpasterstwu i życiu duchowemu wiernych. Dzieliły się zaś one najogólniej na trzy grupy: 1. filologiczne (język Ojców: grecki, łaciński i syryjski), 2. wprowadzające w kontekst historyczno-społeczny Ojców i ułatwiające zrozumienie ich nauki (metodologia i pomoce naukowe do studium Ojców, historia Kościoła starożytnego i filozofii starożytnej, archeologia i sztuka wczesnochrześcijańska, monastycyzm starożytny, początki prawa kościelnego, starożytne religie niechrześcijańskie, zarys historii starożytnej zwłaszcza okresu patrystycznego, herezje wczesnochrześcijańskie, ogólny zarys grecko-łacińskiej literatury klasycznej), 3. przede wszystkim teologia Ojców, wykładana tematycznie i analitycznie, ukazywana w rozwoju poszczególnych jej działów (egzegeza Pisma św., credo chrześcijańskie, nauka trynitarna, chrystologia, pneumatologia, eklezjologia, sakramentologia, liturgia, życie ascetyczne); należało do tego również czytanie i analiza wybranych pism Ojców (lectio Patrum). Dyscyplin tych miano nauczać kursorycznie i monograficznie przez co najmniej 4 lata po ukończonych studiach teologicznych (seminaryjnych): przynajmniej dwa lata do licencjatu i dwa do doktoratu (kurs doktorancki). Rok akademicki miał się rozpoczynać w pierwszym tygodniu października i dzielić się tradycyjnie na dwa semestry.

Słuchacze mieli się dzielić na zwyczajnych (kapłanów lub świeckich po maturze), którzy zmierzając do osiągnięcia stopni akademickich musieli zaliczyć wszystkie wykłady, uczęszczać na przepisane ćwiczenia i seminaria oraz zdać wymaganą ilość egzaminów, i na nadzwyczajnych (przynajmniej po maturze), którzy nie aspirując do stopni akademickich mogą uczęszczać na wybrane przez siebie zajęcia; wszyscy oni winni posiadać przynajmniej podstawową znajomość języka łacińskiego i elementarną języka greckiego. Do osiągnięcia stopni akademickich wymagane było zdanie (ustne lub pisemne) wszystkich przewidzianych egzaminów oraz zaliczenie odpowiednich ćwiczeń i seminariów; uznawane miały być wykłady, ćwiczenia i egzaminy zdane $\mathrm{z}$ tematyki patrystycznej w KUL, ATK lub Papieskich Fakultetach Teologicznych.

Profesorów według proponowanych statutów miał mianować (tak chciał Ksiądz Biskup) dyrektor Instytutu Patrystycznego (czyli ks. bp ordynariusz miejscowy), a zatwierdzać Rada Wydziału Teologicznego w Krakowie. Dzielili się oni na zwyczajnych, którzy mieli przynajmniej doktoraty z teologii ze specjalizacją patrystyczną, i nadzwyczajnych, którzy nie posiadali takich kwalifikacji. Dzielili się oni ponadto na miejscowych (domestici) i zamiejscowych (externi), którymi byli zapraszani z innych Uczelni Wyższych specjaliści. 
A oto proponowane statuty i inne dokumenty tworzonego Instytutu Patrystycznego, przesłane do Kongregacji d/s Wychowania Katolickiego z prośbą o ocenę, uzupełnienia i ewentualną akceptację:

\section{A. STATUTA TARNOVIENSIS INSTITUTI PATRISTICI AD PONTIFICIAM FACULTATEM THEOLOGICAM CRACOVIENSEM AGGREGATI}

Pars prior

\section{DE INSTITUTI PATRISTICI NATURA ET FINE}

1. Institutum Patristicum Tarnoviense studia patristica secundum temporum progressus et necessitates promovere sibi proponit. Tota in sua activitate naturam scientifico-pastoralem servat et hos in specie prosequitur fines:

a) Doctrinam Patrum ita altius excolere atque provehere, ut profundior historiae salutis et mysteriorum Christi intelligentia appareat et ad nostrum temporum vitae Christianae problematum solutionem conferat.

b) E doctrina Patrum, praecipuorum Traditionis testium, ea haurire, quae curam pastoralem nostri temporis adiuverint eique fructus spirituales apportaverint. Idea proinde principalis, quae omnes scholas in Instituto propositas penetrat, haec est, ut omnibus demonstretur, quae doctrina Patrum in singulis nostri temporis disciplinis contulerit et quomodo eas adhuc praesertim in Polonia animare poterit (e.g. subsidia, quae in catechesi et in verbi divini praedicatione adhiberi esse possint praeparando).

c) Professoribus facultatem ad opera Patrum explanandum atque in linguam Polonicam transferendum facere.

d) Alumnos profundius in iis omnibus instituere, quae ad doctrinam SS. Patrum spectant eosquae ad licentiatum et fortasse ad doctoratum necnon laborem scientificum formando.

2. Institutum Patristicum uti sectio pro specialisatione in doctrina Patrum qualificata Pontificiae Facultati Theologicae Cracoviensi est aggregatum, propriis tamen iuribus ad normam statutorum, quae sequuntur, et specialium praescriptorum, quae unoquoque anno a Consilio Academico edi possunt, gaudet. Quae autem Facultas Theologica vi decreti S. Congregationis pro Seminariis et Studiis Universitariis de die 10.XII.1959 a. continua Facultas Theologica Universitatis Jagiellonicae a Summo Pontifice Bonifatio IX 1397 a. erectae in foro ecclesiastico censetur.

3. Institutum Patristicum Tarnoviensae, quamquam omnino suis legibus utitur, diligenter tamen cum Instituto Philosophico-Theologico Tarnoviensi cooperat.

4. Haec sunt auctoritates academicae et Instituti officiales: Magnus Cancellarius Pontificiae Facultatis Theologicae, Director Instituti - Ordinarius loci quo Patristicum invenitur, Decanus Pontificiae Facultatis Theologicae, Prae- 
ses Instituti Patristici, Secretarius eiusdem Instituti necnon Consilium Academicum quod electi professores Instituti Patristici et rector Instituti Theologici constituunt.

5. Gradus academici, qui in Instituto obtinentur ab illis subsignantur, qui id repraesentant, a Magno Cancellario scilicet, a Directore Instituti, a Decano Facultatis Theologicae, Praeside et Secretario Instituti Patristici subsignari debentur.

6. Periodicum officiale Instituti Patristici Tarnoviensis "Tarnowskie Studia Teologiczne" ("Studia Theologica Tarnoviensia") habentur.

7. Institutum Patristicum Tarnoviense s. Joannem Chrysostomum Patronum sibi habet.

Pars altera

\section{DE RATIONE STUDIORUM}

Caput I: De disciplinis docendis

8. Disciplinae patristicae in Instituto illae imprimis proponuntur, quae curae pastorali vitaeque spirituali hominum nostri temporis quam maxime prosunt.

9. Integrum curriculum ad doctoratum post studia philosophico-theologica peracta assequendum quattuor annos complectitur et in duos cyclos dividitur: biennium ad licentiam et biennium ad doctoratum.

10. Priore biennio auditoribus Instituti cursus peculiares ad licentiam in sacra theologia cum specialisatione patristica necessari traduntur. Praelectiones ac seminaria seu proseminaria huius cycli theologiam imprimis $\mathrm{Pa}$ trum sive Orientalium sive Occidentalium ita illustrare debent, ut ex una parte clare appareat, quomodo Revelatio a Patribus intellecta et explicata sit, ex altera autem pateat, quid theologia nostri temporis a Patribus iam receperit quidque adhuc ab illis haurire possit.

11. Omnes scholae atque praelectiones, quae in Instituto docentur, in tres species dividuntur:

I. Philologica: quorum linguae quae viam ad genuinam Patrum mentem constituunt: lingua Latina et Graeca, Graecitas et Latinitas Christiana, lingua Syriaca.

II. Introductiva: quae contextum historico-socialem atque doctrinam Patrum intelligere adiuvant. Haec deinde in tres sectiones subdividuntur:

a) methodica: hermeneutica, methodologia et instrumenta laboris patristici, species litterariae.

b) mundus socialis et culturalis Patrum: Historia Ecclesiae antiquae, elementa philosophiae antiquae, archeologia paleochristiana, institutiones atque organisatio Ecclesiae antiquae, vita monastica, fundamenta Iuris Canonici, religiones non-christianae, historia haeresium, ars paleochristiana, necnon auctores classici, qui in Patres influebant. 
III. theologia Patrum sive thematice sive analytice proposita: cursus patristici peculiares seu monographici, qui „credo” antiquum, fontes fidei, sacramenta atque doctrinam moralem, curam pastoralem necnon principia vitae spiritualis Patrum spectant. Qui cum lectione selectorum genuinorum operum Patrum connectuntur.

12. In biennio ad licentiam alumni praeter cursum Patrologiae fundamentalem necnon quaedam philologica atque introductiva ad mundum graecoromanum, in quo Patres vixerunt, intelligendum necessaria, quae ab omnibus per quattuor semestria frequentanda sunt, item praelectionibus monographicis specialisationi de theologia patristica dedicatis active interesse et de eis examina superare debent. Quinam cursus requisiti et ex quibus examina superari debeant, Consilium Academicum quovis anno constituit. Hoc quoque biennio dissertatio ad licentiam assequendam de aliqua materia patristica una cum professore constituta et a Consilio Academico approbata scribi debet.

13. Post licentiam obtentam alumnus ad doctoratum in studiis patristicis per biennium procedere potest. Ad hunc assequendum saltem per annum quendam numerum cursuum peculiarium frequentet et de eis examina feliciter superet, necesse est; quorum numerus, materia argumentumque a Consilio Academico statuitur. Hoc quoque biennio thesis ad doctoratum paratur, quae saltem tribus semestribus indigebit, ut paretur, nisi Consilium Academicum in aliquo casu particulari aliter iudicaverit, ita tamen, ut saltem in primo anno cursus peculiares frequentari debeant.

14. In prioribus tribus annis studiorum tertia saltem pars cursuum sive qualitative sive quantitative ad modum exercitationum id est proseminariorum vel seminariorum tradi debetur. Quibus alumnus non solum interesse, sed etiam communi cum sodalibus labori et propriis commentationibus operam dare debet. In proseminariis alumni difficiliora genuina Patrum loca legunt atque disceptant, ponderationes recentiorum patristicorum librorum peragunt et primordia laboris scientifici discunt. In seminariis autem peculiares indagationes patristicas sub professorum ductu agunt necnon fragmenta suarum ad licentiam seu lauream dissertationum legunt atque disputant.

15. Annus academicus, qui novem circiter menses complecti debet prima hebdomada mensis octobris initium habet et in duo semestria dividitur: quorum prius ad medium februarium, alterum autem a medio februario ad finem iunii protrahitur. Inscriptione facta auditor Libellum Inscriptionis seu Indicem accepit.

Caput II: De auditoribus

16. Auditores Instituti sunt:

a) ordinarii, qui ad gradus academicos aspirant et proinde omnes scholas, exercitationes et praescripta seminaria frequentant, 
b) extraordinarii, qui ad gradus academicos non aspirant, nonnullas tamen scholas frequentare volunt.

17. Ut quis uti auditor ordinarius ascribi possit testimonium de curriculo philosophico-theologico ad normam can. $1356 \mathrm{CIC}$ in aliquo Seminario Superiore rite expleto referre debet. Si auditor sacerdos est, litteras insuper commendatitias Praelati sui Ordinarii, laicus autem competentis Auctoritatis Ecclesiasticae litteras testimoniales de vita et moribus exhibere debet.

18. Ut quis uti auditor extraordinarius ascribi possit, testimonium saltem de curriculo studiorum (diploma maturitatis) absoluto, quod ad admissionem in universitatem civilem necessarium est necnon licentiam Praesidis Instituti proponere debet.

19. Auditores linguam Latinam elementaque saltem linguae Grecae fundamentalia caleant.

20. Peculiaria praescripta quoad auditorum in Institutum admisionem Consilium Academicum determinat.

\section{Caput III: De examinibus}

21. Nemo ad ullum gradum academicum promoveri potest, nisi omnibus exercitiis ad eum adipiscendum praescriptis rite satisfecerit.

22. Examina vel ore vel scripto fieri possunt. Examen orale per aliquam quoque brevem investigationem private scriptam, quae deinde a duobus censoribus adprobetur, substitui potest. Si de seminariis vel privata professoris lectione agitur, sufficit, ut professor iudicium scriptum de effectibus alumni det.

23. Institutum agnoscit omnes cursus et examina de re patristica, tam in Universitate Catholica Lublinensi quam in Academia Theologica Varsaviensi necnon in Pontificiis Facultatibus Theologicis superata, iis tamen suppletis, quae ad validitatem examinum finalium in Instituto Patristico praescribuntur.

24. Tres sunt examinum sessiones annuales: aestiva, autumnalis et hiemalis; harum tempus Consilium Academicum determinat. Alumnus qui in periculo subeundo non est probatus, illud iterandi ius habet, non tamen in eadem sessione.

25. Ut quis ad examina superanda admittatur, Libellum Inscriptionis seu Indicem duabus ultimis hebdomadis uniuscuiusque semestris ad frequentationis attestationem iis professoribus signandum offert, quorum scholas frequentat.

26. Ut quis ad annum sequentem promoveatur, requiritur ut ex disciplinis saltem principalibus examina feliciter superet.

27. Examen finale ad licentiam ore fit et integram traditarum hoc biennio disciplinarum cognitionem demonstrare debet. In hoc examine quinque saltem examinatores adsint, necesse est. 


\section{Caput IV: De gradibus academicis}

28. In Instituto Patristico hi gradus academici conferuntur: licentia et laurea seu doctoratus.

29. Gradus licentiae testatur de frequentatis cursibus profundioribus de aliqua specialisatione, de introductione in scientificam investigandi methodum et de competentia ad ulteriorem investigationem. Licentia non ante expletum annum secundum ab initio curriculi patristici confertur. In biennio autem ad licentiam cursus praesertim speciales praebentur, qui profundiori modo aspectum aliquem theologiae scientifice illustrent, ut ipsis alumnis exemplum altioris investigationis praebeant.

30. Ut quis licentia decoretur, requiritur ut:

a) lectiones et exercitationes de praescriptis patristicis ancillaribusque disciplinis per biennium frequentaverit et examina de designatis superaverit. In hoc biennio alumni 48 saltem certificationes (credits) assequi debent (Patrologia fundamentalis - 6 certificationes, Theologia Patrum - 18 certificationes, Mundus culturalis et socialis Patrum - 8 certificationes, Introductio in studium Patrum -8 certificationes, Lectio Patrum - 8 certificationes), quarum unaquaeque 10-12 lectiones vel seminaria complectere debet. De unoquoque cursu, qui duas „certificationes" complectere poterit, examen semper superari debet,

b) seminario scientifico per biennium interfuerit,

c) idoneitatem suam ad laborem scientificum in disciplinis theologicopatristicis per scriptam dissertationem a duobus professoribus, moderatore scilicet et censore, a Consilio Academico designatis adprobatam ostenderit,

d) secundum iudicium moderatoris dissertationis sufficientem scientiam earum linguarum habeat, quae ad legendos fontes ut indispensabiles habentur,

e) cognitionem fundamentalem unius saltem linguae modernae habeat,

f) examen generale de potioribus disciplinis, quae in biennio ad licentiam traditae sunt, coram quinque saltem professoribus superaverit.

31. Laurea seu doctoratus gradus academicus habetur, quo cognoscitur, eum qui hoc gradu donatur peculiaribus experimentis ac praecipue opere de re patristica scripto, quod ad scientiae profectum conducat, suae maturitatis scientificae testimonium dedisse.

32. Ut proinde alicui doctoratus conferatur, requiritur ut:

a) iam licentia in sacra theologia decoratus sit,

b) cursus ad doctoratus requisitos frequentaverit et de eis examina superaverit. Qui autem licentiam in theologia in alia facultate assecutus est, cursui ad doctoratum ascribi potest, dummodo scholas patristicas cum exercitationibus et examinibus ordinarie per biennium distributas frequentet. Antequam tamen doctoratum assequi possit quendam nume- 
rum examinum a Consilio Academico designatorum superare debet, inter quae etiam cursus patristici ad licentiam adnumerari possunt.

c) seminario scientifico per unum saltem annum in assistentia moderatoris thesis interfuerit.

d) duas linguas modernas passive saltem didicerit, de quibus examine probetur.

e) thesim doctoralem coram quinque saltem professoribus defenderit necnon examen de quaestionibus a moderatore thesis designatis superaverit. Quae thesis a moderatore necnon a duobus censoribus a Consilio Academico designatis, rerum Patrum peritis, scripte recensetur, quorum tamen unus de alia Facultate invitatur.

Caput V: De professoribus

33. Professores a Directore Instituti, id est Ordinario loci nominantur et a Consilio Facultatis Theologicae adprobantur.

34. Professores ordinarii illi vocantur, qui saltem laurea in theologia cum specialisatione patristica ornantur.

35. Professores Instituti assidue debent studere, ut eorum scientia patristica ac praeparatio ad munus docendi adimplendum magis magisque crescat et ad profectum theologiae vere conferat.

36. In suis praelectionibus ac seminariis professores non tam nimia philologica vel singula particularia theologica Patrum sciscitari, quam potius integram singularum disciplinarum theologiae sinthesim, quae magis hominibus nostri temporis prosit, praebere debent.

37. Deficiente plena copia librorum de rebus patristicis tractantium professores alumnis scripta summaria suarum praelectionum suppeditare conari debent, quibus hi in praeparandis examinibus adiuvari possint. Alumni tamen tum e fontibus tum ex libris auxiliaribus a professoribus indictis haurire horumque rationem reddere obligantur.

\section{B. HISTORIAE INSTITUTI PHILOSOPHICO-THEOLOGICI TARNOVIENSIS BREVIS EXPLANATIO}

Fundamenta iuridica Instituti Philosophico-Theologici Tarnoviensis Papa Pius VII bulla "Studiorum paterni affectus" die 20. IX. 1821 a. edita posuit.

Instituta philosophico-theologica in Gallicia, etiam Tarnoviae vera erant facultatum theologicarum in universitatibus Galliciae, i.e. Jagiellonica Cracoviae et Joannis Casimiri Leopoli, imagine idque tam ratione singularum facultatum organisationis, quam docendi rationis. Qua de causa, qui studium 
theologicum modo normali aut in universitatis facultate, aut in instituto provinciali absolverit, non solum re ipsa, sed etiam modo formali universitatem absolvisse putabatur.

Institutum Philosophico-Theologicum Tarnoviense potestas civilis iam ante secundum bellum mundiale legitime approbavit. Statum privilegiatum Instituti Philosophico-Theologici Tarnoviensis uti Instituti cognitioni et scientiae dedito addita instructioni ministri Institutionis Publicae de die 11 Februarii 1957 a. Nr 435/57-XI confirmaverunt, quae quidem Instituta Philosophico-Theologica Premisliae, Tarnoviae, Congregationis Missionum Cracoviae, Societatis Jesu Lublini „scholis scientificis” nominant, interdum cetera instituta theologica inter seminaria tantum sunt enumerata. Eventus, qui ad usum vitae e statu descripto sequebatur is erat, quod Institutum Philosophico-Theologicum Tarnoviense absolventes, gradus academicos in Polonicis universitatibus sine necessitate scholas hisce in universitatibus frequentandi, obtinere poterant. Studia enim in hoc Instituto omnino affirmabantur. Qui status usque ad facultatum theologicarum in universitatibus a potestate civili anno 1953 dissolutionem perduravit.

Ineunte anno academico 1977/78 omnes Instituti Philosophico-Theologici Tarnoviensis alumni numerum 270 excesserunt. Lectiones in Instituto alumni Congregationis S. Philippi Nerii quoque frequentant. Die 22. II. 1975 a. inter Institutum Theologicum Tarnoviense et Pontificiam Facultatem Theologicam Cracoviae conventio de mutua cooperatione auxilioque in campo didactico, scripta edendi et doctrinali facta est.

\section{COLLEGIUM PROFESSORUM}

I. Professores domestici, qui iam in Instituto Theologico docent :

1. Rev. Michael BEDNARZ

2. Rev. Thaddaeus BRZEGOWY

3. Eppus Ladislaus BOBOWSKI

4. Rev. Joannes DUDZIAK

5. Rev. Vojtechus KANIA
- Dr theologiae et lic. Sacrae Scripturae, prof. Sacrae Scripturae

- Dr theologiae et lic. Sacrae Scripturae, prof. exegesis Sacrae Scripturae

- Dr theologiae spiritualis, prof. theologiae spiritualis

- Dr habilit. Iuris Canonici, prof. Iuris Canonici in Instituto Theologico Tarnoviensi necnon in Pontificia Facultate Theologica Vratislaviensi

- Dr habilit. theologiae cum specialisatione in scientiis patristicis, prof. patrologiae et linguae syriacae 
6. Rev. Eugenius KRĘŻEL

7. Rev. Casimirus KUPIEC

8. Rev. Stanislaus LONGOSZ

9. Rev. Eduardus ŁOMNICKI

10. Rev. Boleslaus MARGAŃSKI

11. Rev. Adamus NOWAK

12. Rev. Antonius PACIOREK

13. Rev. Leopoldus REGNER

14. Rev. Ladislaus SZCZEBAK

15. Rev. Ladislaus SZEWCZYK

16. Rev. Casimirus SZWARGA
- Dr philosophiae, mgr theologiae, prof. catholicae doctrinae socialis

- Dr theologiae orientalis, prof. theologiae dogmaticae

- Dr theologiae et in scientiis patristicis, lic. historiae Ecclesiae Antiquae, mgr philologiae classicae, prof. patrologiae et linguae latinae

- Dr theologiae apologeticae, mgr philologiae classicae, prof. linguae latinae

- Dr theologiae cum specialisatione in liturgica, prof. theologiae liturgicae

- Dr rerum bibliothecarum, mgr theologiae, prof. historiae Ecclesiae

- Dr theologiae, lic. Sacrae Scripturae, mgr philologiae classicae, prof. exegesis Sacrae Scripturae

- Dr habilit. Philosophiae, mgr theologiae, prof. philosophiae

- Dr artis ecclesiasticis, prof. historiae artis ecclesiasticae

- Dr philosophiae, mgr theologiae, prof. psichologiae

- Dr historiae ecclesiasticae, prof. historiae ecclesiasticae

II. Professores externi, qui de aliis Facultatibus Universitatibusque invitantur

1. Rev. Romanus ANDRZEJEWSKI - Dr litterarum classicarum, prof. patrologiae et linguae latine in Seminario Superiore Vladislaviensi

2. Rev. Andreas BOBER

- Dr theologiae cum specialisatione patristica, mgr philologiae classicae,

prof. patrologiae in Catholica

- Universitate Lublinensi

3. Rev. Bogdanus CZĘSZ

- Dr theologiae et litterarum paleochristianarum, prof. patrologiae in Pontificia Facultate Theologica Posnaniae 
4. Rev. Vencislaus EBOROWICZ - Dr habilit. Theologiae cum specialisatione patristica, prof. patrologiae in Seminario Superiore Pelplinensi

5. Barbara FILARSKA

- Dr habilit. Archeologiae, prof. archeologiae et artis paleochristianae in Catholica Universitate Lublinensi

6. Rev. Ladislaus GŁADYSZEWSKI - Dr philologiae classicae, lic. theologiae,

prof. patrologiae et linguae latinae in Seminario Superiore Gnesnensi

7. Rev. Stanislaus KALINKOWSKI - Dr litterarum classicarum, prof. linguae Graecae in Academia Theologiae Catholicae Varsoviae

8. Rev. Boleslaus KUMOR

- prof. dr habilit. Historiae ecclesiasticae in Catholica Universitate Lublinensi

9. Rev. Aemilus STANULA

- Dr theologiae cum specialisatione patristica, mgr philologiae classicae,

prof. patrologiae in Academia Theologiae Catholicae Varsoviae

10. Rev. Vincentius MYSZOR

- Dr theologiae cum specialisatione patristica, peritus linguae copticae,

prof. patrologiae et linguae copticae in Academia Theologiae Catholicae Varsoviae

11. Leocadia MAŁUNOWICZ

- Prof. dr habilit. Litterarum classicarum,

prof. litterarum classicarum latinarum necnon praeses Instituti Studiorum de Antiquitate Christiana in Catholica Universitate Lublinensi

12. Rev. Casimirus OBRYCKI

- Dr philologiae classicae, lic. theologiae,

prof. linguae latinae in Academia Theologiae Catholicae Varsoviae

13. Rev. Stephanus PIESZCZOCH - Dr theologiae cum specialisatione patristica, 
prof. patrologiae in Seminario $\mathrm{Su}$ periore Gnesnensi

14. Rev. Marcus STAROWIEYSKI - Dr theologiae cum specialisatione patristica, mgr philologiae classicae,

prof. patrologiae in Pontificia Facultate Theologica Varsoviae

15. Rev. Eduardus STANIEK

- Dr theologiae cum specialisatione patristica, prof. patrologiae in Pontificia Facultate Theologica Cracoviae

\section{DISCIPLINAE IN CURSU PATRISTICO AD LICENTIAM DOCENDAE}

I. Patrologia fundamentalis:

1. Patrologia fundamentalis praenicaena. . . . 1 hora per 2 semestria Rev. Dr W. Myszor

2. Patrologia fundamentalis postnicaena ...... $1 \mathrm{~h}$. per 2 semestria Rev. Dr Ae. Stanula 3. Patrologia Syriaca . . . . . . . . . . . 1 h. per 1 semestre Rev. Doc. W. Kania

II. Theologia Patrum:

1. Christologia Patrum saeculi II-III . ........ 1 h. per 1 semestre Rev. Dr S. Longosz

2. Christologia Patrum saeculi IV-V . . . . . . 1 h. per 1 semestre Rev. Dr S. Longosz

3. Exegesis Patrum saeculi II-III . . . . . . . . 1 h. per 1 semestre Rev. Dr Ae. Stanula

4. Exegesis Patrum saeculi IV-V . . . . . . 1 h. per 1 semestre Rev. Dr Ae. Stanula

5. Ecclesiologia Patrum II-III saeculi . . . . . . 1 h. per 1 semestre Rev. Dr E. Staniek

6. Ecclesiologia Patrum IV-V saeculi ......... 1 h. per 1 semestre Rev. Dr E. Staniek

7. Liturgia in aevo patristico ........... 1 h. per 1 semestre

Rev. Dr B. Margański

8. Catechesis ac praedicatio Patrum ......... 1 h. per 1 semestre Rev. Dr R. Andrzejewski

9. Sacramenta in doctrina Patrum......... 1 h. per 2 semestria Rev. Dr E. Staniek

10. Cura pastoralis apud Joannem Chrysostomum . 1 h. per 1 semestre Rev. Doc. V. Kania 11. Theologia Judaeochristianorum ......... $1 \mathrm{~h}$. per 1 semestre Rev. Dr M. Bednarz 
12. Traditionis notio atque auctoritas apud Patres. . $1 \mathrm{~h}$. per 1 semestre Rev. Dr S. Longosz

13. Oppositio apologetarum contra culturam classicam1 h. per 1 semestre

Rev. Dr E. Łomnicki

14. Symbola fidei Ecclesiae antiquae ........ 1 h. per 1 semestre

Rev. Dr S. Longosz

15. Influxus Patrum in theologiam posteriorem... . $1 \mathrm{~h}$. per 1 semestre

Rev. Dr S. Pieszczoch

16. Influxus auctorum classicorum in doctrinam Patrum 1 h. per 1 semestre

Prof. Doc. L. Małunowicz

17. Gnosticismus eiusque influxus in theologiam... $1 \mathrm{~h}$. per 1 semestre Rev. Dr W. Myszor

18. Apocrypharum auctoritas in Ecclesia antiqua .. 1 h. per 1 semestre

Rev. Dr M. Starowieyski

19. Mariologia Patrum............... 1 h. per 1 semestre

Rev. Dr M. Starowieyski

20. Homilia apud Patres. . . . . . . . . . . . 1 h. per 1 semestre

Rev. Dr C. Obrycki

21. Antropologia in aevo patristico........ $1 \mathrm{~h}$. per 1 semestre Rev. Dr L. Szewczyk

22. Principia theologiae spiritualis Patrum ...... 1 h. per 1 semestre Rev. Dr L. Bobowski

23. Ius canonicum temporis Patrum ......... 1 h. per 1 semestre

Rev. Doc. J. Dudziak

24. De gratia apud Augustinum ........... 1 h. per 1 semestre

Rev. Doc. V. Eborowicz

25. Principia theologiae de Spiritu Sancto........ 1 h. per 1 semestre Rev. Dr B. Częsz

26. Controversia Ariana. . . . . . . . . . 1 h. per 2 semestria Rev. Dr S. Longosz

27. Receptio Patrum in Polonia .......... 1 h. per 1 semestre Rev. Dr A. Bober

28. Kalendaria atque Martyrologia antiqua...... 1 h. per 1 semestre Rev. Dr S. Pieszczoch

29. Oratio apud Patres.............. 1 h. per 1 semestre

Rev. Doc. H. Wójtowicz

30. Theologia historiae apud S. Irenaeum. . . . . $1 \mathrm{~h}$. per 1 semestre Rev. Dr B. Częsz

III. Mundus socialis et culturalis Patrum:

1. Historia Ecclesiae Antiquae. . . . . . . . 1 h. per 2 semestria Rev. Dr A. Nowak

2. Historia Imperii Romani $\ldots \ldots \ldots \ldots \ldots \ldots 1$ h. per 1 semestre

Rev. Dr K. Szwarga

3. Organisatio atque institutiones Ecclesiae antiquae $1 \mathrm{~h}$. per 1 semestre 
Rev. Prof. B. Kumor

4. Archeologia christiana . . . . . . . . . . . 1 h. per 1 semestre

Doc. B. Filarska

5. Philosophiae antiquae quaestiones selectae.... $1 \mathrm{~h}$. per 1 semestre

Rev. Doc. L. Regner

6. Ius Canonicum tempore Patrum......... 1 h. per 1 semestre

Rev. Doc. J. Dudziak

7. Religiones non christianae hellenisticae ..... 1 h. per 1 semestre Rev. Dr L. Gładyszewski

8. Vita monastica tempore Patrum ......... 1 h. per 1 semestre

IV. Introductio in studium Patrum:

Rev. Dr M. Starowieyski

1. Instrumenta laboris patristici $\ldots \ldots \ldots \ldots \ldots 1 \mathrm{~h}$. per 1 semestre

Dr S. Kalinkowski

2. Methodologia patristica ............ 1 h. per 1 semestre Rev. Dr A. Bober

3. Lingua Graeca patristica ............ $1 \mathrm{~h}$. per 4 semestria

Rev. Dr A. Paciorek

4. Lingua Latina Patristica.............. 1 h. per 3 semestria

Rev. Dr E. Łomnicki

5. Lingua Syriaca. . . . . . . . . . . . 1 h. per 2 semestria

Rev. Doc. W. Kania

6. Formae litterales quibus Patres mentem suam exprimebant

1 h. per 1 semestre

Rev. Dr L. Gladyszewski

V. Lectio Patrum

SEMESTRE I

\section{ORDO LECTIONUM}

\begin{tabular}{|c|l|}
\hline Hora & \multicolumn{1}{c|}{ Argumentum } \\
\hline 8.00 & Lingua Latina patristica - Rev. dr E. Łomnicki \\
\hline 9.00 & Patrologia fundamentalis praenicaena - Rev. dr V. Myszor \\
\hline 10.00 & Patrologia fundamentalis praenicaena - Rev. dr V. Myszor \\
\hline 11.00 & Instrumenta laboris patristici - dr S. Kalinkowski \\
\hline 12.00 & Lingua Graeca patristica - Rev. dr A. Paciorek \\
\hline 14.00 & Historia Ecclesiae Antiquae - Rev. dr A. Nowak \\
\hline 15.00 & Historia Imperii Romani - Rev. dr K. Szwarga \\
\hline 16.00 & $\begin{array}{l}\text { Organisatio atque institutiones Ecclesiae Antiquae - Rev. prof. dr } \\
\text { B. Kumor }\end{array}$ \\
\hline 17.00 & $\begin{array}{l}\text { Questiones selectae philosophiae antiquae eiusque influxus in do- } \\
\text { ctrinam Patrum - Rev. doc. L. Regner }\end{array}$ \\
\hline 18.00 & Homilia apud Patres - Rev. dr K. Obrycki \\
\hline
\end{tabular}


SEMESTRE II

\begin{tabular}{|c|l|}
\hline Hora & \multicolumn{1}{c|}{ Argumentum } \\
\hline 8.00 & Lingua Latina patristica - Rev. dr E. Łomnicki \\
\hline 9.00 & Patrologia fundamentalis praenicaena - Rev. dr Ae. Stanula \\
\hline 10.00 & Patrologia fundamentalis praenicaena - Rev. dr Ae. Stanula \\
\hline 11.00 & Archeologia christiana - doc. dr B. Filarska \\
\hline 12.00 & Lingua Graeca patristica - Rev. dr A. Paciorek \\
\hline 14.00 & Historia Ecclesiae Antiquae - Rev. dr A. Nowak \\
\hline 15.00 & Christologia Patrum saec. II-IV - Rev. dr S. Longosz \\
\hline 16.00 & $\begin{array}{l}\text { Lectio selectorum textuum de Christo a Tertulliano et Origene do- } \\
\text { centibus - Rev. dr S. Longosz }\end{array}$ \\
\hline 17.00 & Exegesis Patrum saec. II-IV - Rev. dr Ae. Stanula \\
\hline 18.00 & $\begin{array}{l}\text { Lectio selectorum textuum de exegesi patristica agentium - Rev. dr } \\
\text { Ae. Stanula }\end{array}$ \\
\hline
\end{tabular}

SEMESTRE III

\begin{tabular}{|c|c|}
\hline Hora & Argumentum \\
\hline 8.00 & Lingua Latina patristica - Rev. dr E. Łomnicki \\
\hline 9.00 & Lingua Graeca patristica - Rev. dr A. Paciorek \\
\hline 10.00 & Christologia saeculi IV-VI - Rev. dr S. Longosz \\
\hline 11.00 & $\begin{array}{l}\text { Lectio selectorum textuum de christologia Patrum saec. IV-VI trac- } \\
\text { tantibus - Rev. dr S. Longosz }\end{array}$ \\
\hline 12.00 & Exegesis Patrum saec. II-III - Rev. dr Ae. Stanula \\
\hline 14.00 & $\begin{array}{l}\text { Lectio textuum de exegesi Patrum saec. II-III tractantibus - Rev. dr } \\
\text { Ae. Stanula }\end{array}$ \\
\hline 15.00 & Mariologia Patrum - Rev. dr M. Starowieyski \\
\hline 16.00 & $\begin{array}{l}\text { Lectio textuum de Maria saec. Patrum tractantium - Rev. dr } \\
\text { M. Starowieyski }\end{array}$ \\
\hline 17.00 & Catechesis atque predicatio Patrum - Rev. dr R. Andrzejewski \\
\hline 18.00 & $\begin{array}{l}\text { Lectio selectorum textuum de catechesi agentium }- \text { Rev. dr } \\
\text { R. Andrzejewski }\end{array}$ \\
\hline
\end{tabular}

SEMESTRE IV

\begin{tabular}{|c|l|}
\hline Hora & \multicolumn{1}{c|}{ Argumentum } \\
\hline 8.00 & Patrologia Syriaca - Rev. doc. dr V. Kania \\
\hline 9.00 & Lingua Graeca patristica - Rev. dr A. Paciorek \\
\hline 10.00 & Ecclesiologia Patrum saec. I-III - Rev. dr E. Staniek \\
\hline 11.00 & Lectio selectorum textuum de Ecclesia agentium - Rev. dr E. Staniek \\
\hline 12.00 & Liturgia in aevo patristico - Rev. dr B. Margański \\
\hline 14.00 & Liturgia in aevo patristico - Rev. dr B. Margański \\
\hline 15.00 & Traditionis notio atque auctoritas apud Patres - Rev. dr S. Longosz \\
\hline 16.00 & $\begin{array}{l}\text { Lectio selectorum textuum de traditione agentium - Rev. dr } \\
\text { S. Longosz }\end{array}$ \\
\hline 17.00 & Sacramenta in doctrina Patrum - Rev. dr E. Staniek \\
\hline 18.00 & Sacramenta in doctrina Patrum - Rev. dr E. Staniek \\
\hline
\end{tabular}


SEMESTRE V

\begin{tabular}{|c|l|}
\hline Hora & \multicolumn{1}{|c|}{ Argumentum } \\
\hline 8.00 & Ecclesiologia Patrum - Rev. dr E. Staniek \\
\hline 9.00 & Symbola Ecclesiae Antiquae - Rev. dr S. Longosz \\
\hline 10.00 & $\begin{array}{l}\text { Lectio selectorum symbolorum Ecclesiae antiquae - Rev. dr S. Lon- } \\
\text { gosz }\end{array}$ \\
\hline 11.00 & $\begin{array}{l}\text { Gnosticismus eiusque influxus in theologiam Patrum - Rev. dr } \\
\text { V. Myszor }\end{array}$ \\
\hline 12.00 & Lectio selectorum textuum Gnosticorum - Rev. dr V. Myszor \\
\hline 14.00 & Methodologia patristica - Rev. dr A. Bober \\
\hline 15.00 & Antropologia Patrum - Rev. dr L. Szewczyk \\
\hline 16.00 & $\begin{array}{l}\text { Lectio textuum de antropologia Patrum tractantium - Rev. dr } \\
\text { L. Szewczyk }\end{array}$ \\
\hline 17.00 & Oratio apud Patres - Rev. doc. dr H. Wójtowicz \\
\hline 18.00 & $\begin{array}{l}\text { Lectio atque analysis selectarum antiquarum orationum - Rev. doc. } \\
\text { dr H. Wójtowicz }\end{array}$ \\
\hline
\end{tabular}

A oto pierwsza odpowiedź anonimowego konsultora Kongregacji ds. Wychowania Katolickiego na przesłane wyżej jeszcze w sposób nieoficjalny dokumenty:

\section{APPUNTO}

\section{CIRCA IL COSTITUENDO ISTITUTO PATRISTICO TARNOVIENSE:} (Considerazioni)

La Pontificia Facoltà Teologica di Kraków ha presentanto, in modo non ufficiale, un progetto di Statuti del costituendo Istituto Patristico Tarnoviense, pregando di fornire alcuni orientamenti atti ad impostare, conformemente alla legge accademica della Chiesa, la struttura e l'organizzazione dell' Istituto. Detto progetto è composto di due parti, contenenti complessivi 57 articoli. Insieme ad esso sono stati presentati i seguenti documenti i „Disciplinae docendae”, „Studiorum adiumenta”, „Collegium Professorum” e una breve storia dell'Istituto Fil.-Teol. di Tarnów. Allo scopo di facilitare i lavori preparatori all'erezione ed alla formulazione degli Statuti, si propongono le seguenti considerazioni:

A. Considerazioni previe:

1. Dall'esame della documentazione presentata e da altre informazioni si ricava l'impressione che l'ambiente teologico di Tarnów sia realmente in grado di organizzare un Istituto Patristico. Si richiede, tuttavia, un ulteriore fermo impegno delle autorità diocesane per migliorare il corpo docente, anzitutto nei riguardi della specializzazione patristica. Si rileva peraltro l'esistenza di una rivista teologica, che offrirà la possibilità di pubblicare i frutti del lavoro dell'Istituto. 
2. L'Istituto, una volta eretto, diverrà ente accademico, e richiederà perciò l'attuazione delle condizioni spettanti a tale condizione, quali sono comunemente richieste dalle leggi accademiche canonica e nazionale polacca. Per la serietà e l'autorità dei gradi accademici che saranno rilasciati, si raccomanda di adattarsi accuratamente anche alle esigenze di quest'ultima. Si rileva che specialmente la qualità dal corpo docente dovrà rispondere anche alle esigenze universitarie del paese (abilitazione).

3. Non si esprime qui un giudizio circa il progetto della ,ratio studiorum": esso spetta in prima istanza alla Facoltà Cracoviense, che ha l'obbligo di esaminare tutte le condizioni accademiche da soddisfarsi dal futuro Istituto Tarnoviense: struttura del curricolo, organizzazione del programma, condizioni per il rilascio dei gradi, specializzazione patristica della biblioteca, qualità del corpo docente, peculiarità degli studenti, ecc. La domanda di erezione, da dirigersi dal Gran Cancelliere alla S. Congregazione, dovrà essere accompagnata dal giudizio scritto della facoltà, che si esprimerà su tali condizioni accademiche a su altre eventuali richieste da soddisfarsi in futuro.

4. L'intera pratica dovrà essere accompagnata dalla raccomandazione della Commissione Episcopale per gli Studi Superiori, in cui essa giudichi se l'impostazione dell'Istituto corrisponda veramente alla legge e alle prassi universitarie vigenti a livello nazionale per gli studi ecclesiastici.

B. Formulazione degli Statuti:

5. La stesura degli Statuti dovrà tener conto, „mutatis mutandis”, delle „Normae ad Universitatis vel Facultatis Statuta conficienda” (ALLLEGATO I), che offrono sinteticamente i principali capi da introdurre in ogni Statuto, e cioè: „De nomine, natura et fine Instituti; De regimine; De docentibus; De studentibus; De officialibus; De ratione studiorum; De gradibus academicis; De rebus didacticis; De rebus oeconomicis; De relationibus cum aliis Institutis vel Facultatibus".

6. L'Istituto Patristico Tarnoviense sarà organizzato come parte integrante della Pontificia Facoltà Teologica di Kraków; di conseguenza, pertanto, dovrà recepire in linea di massima le prescrizioni statutarie della Facoltà medesima, per il motivo della dovuta conformità nell'impostazione dei problemi accademici comuni.

7. L'Istituto, essendo un ente accademico, godrà dell'autonomia accademica prevista dalle prescrizioni ecclesiastiche in materia; essa verrà anzitutto concretizzata nel principio generale secondo il quale spetta al Consiglio dell'Istituto, di proporre i candidati per le nomine da farsi dalle competenti autorità, seguendo in ciò una procedura da stabilirsi negli Statuti.

C. Considerazioni particolari:

8. Figura giuridico-accademica dell'Istituto. Eretto in ente accademico ecclesiastico, esso avrà come scopo la duplice finalità: a) dell'insegnamento e b) della ricerca scientifici nell'ambito del suo interesse, con 
rilascio finale dei gradi accademici. Esso farà parte della Pontificia Fac. Teol. Cracoviense mediante la ,figura dell'incorporazione" e sarà essenzialmente un Istituto teologico, con indirizzo patristico. Per la Facoltà esso costituirà un suo secondo ciclo con specializzazione in patrologia. Nel decreto di erezione quindi esso verrà incorporato alla Facoltà Teologica quale suo secondo ciclo caratterizato dalla patrologia. Non si tratta in questo caso di aggregazione, come prospetta il progetto: (questa infatti riguarda il primo e il secondo ciclo di Facoltà considerati come un tutto organico); si tratta invece di incorporazione; figura che riguarda il secondo e/o terzo ciclo di Facoltà.

9. Autorità. Per il fatto di essere costituito quale parte della Facoltà Teologica di Kraków, l'Istituto verrà a trovarsi sotto le autorità della Facoltà e cioè del suo Gran Cancelliere, del suo Consiglio di Facoltà, del suo decano. Si suppone comunque che dette autorità debbano riguardare solo l'aspetto accademico. L'Istituto poi avrà come autorità immediate un suo vice-Cancelliere, costituito dall'Ordinario del luogo, con autorità limitata ai soli affari dell'Istituto Tarnoviense (non cioè estesa all'intera Facoltà), un suo Consiglio di Istituto, composto dei professori ordinari, straordinari, docenti (abilitati) e dei delegati delle altre componenti dell'Istituto, un Preside da elegersi tra i professori stabili, per il tempo determinato dagli Statuti.

10. Docenti. Sono da prevedersi negli Statuti i consueti vari ordini dei docenti: ordinari, straordinari, docenti (stabili) ed invitati. Le nomine del preside e dei professori, e le successive promozioni di questi, seguiranno la seguente procedura: il primo passo compete al Consiglio dell'Istituto, che valuta il candidato secondo i criteri fissati dalla legge accademica canonica e lo propone poi al Vice-Cancelliere. Questi trasmette, con il proprio consenso, la domanda e la relativa documentazione al Consiglio della Facoltà, il quale riconsidera il merito della candidatura. Se l'esito sarà positivo, il Gran Cancelliere chiederà il „nihil obstat” della S.Congregazione; ricevuto il quale, il Gran Cancelliere medesimo emanerà l'atto di nomina, firmato da lui e dal Vice-Cancelliere. Per i docenti, occorrerà soddisfare le varie prescrizioni fissate al riguardo dalla Facoltà Cracoviense nei suoi Statuti. Si dovrà stabilire anche il modo della partecipazione del Consiglio dell'Istituto ai lavori del Consiglio Accademico della Facoltà.

11. Studenti. Possono essere ammessi nell'Istituto Tarnoviense in qualità di studenti ordinari i coli candidati in possesso del primo grado accademico canonico in S. Teologia (Baccalaureato o equivalente „Magisterium"). Quanto all'ammissione di studenti che abbiano regolarmente percorso il curricolo filosofico-teologico prescritto ai fini del sacerdozio, ma che siano privi del grado di primo ciclo, è da tenersi presente il prescritto dell'art. 43, a, degli Statuti della Facoltà Cracoviense, che la vieta. Per questi studenti non in possesso del grado di 
primo ciclo, potranno essere organizzati altri curricoli, che rilascino loro un apposito diploma, escluso comunque il grado.

12. Officiali. Si preveda la costituzione di una segreteria dell'Istituto, con un segretario e uno/due addetti, precisando negli Statuti le loro attribuzioni, la procedura della loro nomina e la loro durata in carica.

13. „Ratio studiorum”. Negli Statuti sono da stabilirsi le linee generali degli studi patristici previsti per l'Istituto. In un documento a parte (e cioè nella ,Ratio studiorum”), come è stato già proposto, si specificheranno esattamente le determinazioni particolari e le materie da studiare.

14. Gradi accademici. L'Istituto rilascerà il secondo grado accademico, la licenza. Peraltro, esso desidererebbe rilasciare anche il dottorato. In linea di principio, non si è contrari ad, accogliere tale desiderio, giacché si suppone che il corpo docente in grado di condurre il curricolo „ad licentiam” sia equalmente in grado di condurre lo studente ,ad doctoratum". Si può perciò nel Decreto e negli Statuti prevedere anche il rilascio del dottorato, tenendo tuttavia sospesa la facoltà di concedere il dottorato per un certo tempo. Si tratta infatti anzitutto di verificare, nel periodo di sperimentazione, il funzionamento e gli studi del curricolo ,ad licentiam”. Per la concessione dei gradi si dovranno recepire negli Statuti le condizioni e le prescrizioni valevoli per la Facoltà Cracoviense, tenendo presente che sarà sempre la Facoltà a rilasciare i gradi, sia pure attraverso l'Istituto.

(8 maggio 1978)

W przytoczonej wyżej odpowiedzi konsultor Kongregacji sugeruje, jak widać, szereg cennych, ale modyfikujących uwag. Najpierw Instytut nie może być do Fakultetu ,agregowany”, ale ,,inkorporowany”, bo stanowi tylko drugi jego cykl ze specjalizacją patrystyczną. Ordynariusz miejscowy nie może być dyrektorem Instytutu, mającym nad nim pełną władzę i mianującym m.in. uczących w nim profesorów, ale tylko Wicekanclerzem, do którego należą jedynie bezpośrednie (głównie finansowe) sprawy Instytutu, a pełną władzę nad nim będą sprawować Wielki Kanclerz, Rada Wydziału i jej dziekan, proces zaś wyłaniania prezesa i profesorów Instytutu winien się rozpoczynać od Rady Akademickiej Instytutu poprzez Wicekanclerza, Radę Wydziału i Wielkiego Kanclerza, który dokonuje aktu nominacji; podobnie stopni naukowych udziela Wydział poprzez Instytut. Konsultor sugeruje ponadto, by statuty z jednej strony dostosować szczegółowiej do rzymskich Normae ad Universitatis vel Facultatis statuta conficienda i do statutów Wydziału Teologicznego w Krakowie, z drugiej zaś, zwłaszcza odnośnie do profesorów, lepiej je adaptować do postulatów uniwersyteckiego prawa polskiego, gdzie wymaga się habilitacji, oraz zapisać jasno ich kategorię i proces ich wyłaniania; należy też w nich uwzględnić miejsce sekretariatu Instytutu i określić jasno prawa urzę- 
dującego w nim sekretarza Instytutu. Domaga się również zwiększenia liczby profesorów ze specjalizacją patrystyczną, a w innym piśmie - jasnego zagwarantowania odpowiednich funduszów na specjalistyczną bibliotekę i opłatę profesorów Instytutu. W przyszłości zaś oficjalna prośba o erygowanie Instytutu Patrystycznego w Tarnowie, skierowana do Kongregacji przez Wielkiego Kanclerza, winna być poparta, zarówno pisemną pozytywną opinią Fakultetu Teologicznego o programie i statutach tworzonego Instytutu, jak i rekomendacją Komisji Episkopatu d/s Nauki i Studiów Wyższych stwierdzającą, że on odpowiada wymogom polskiego prawa kościelnego i uniwersyteckiego.

Po otrzymaniu powyższej odpowiedzi ks. biskup J. Ablewicz w niedługim czasie zrezygnował $\mathrm{z}$ dalszych starań o erygowanie Instytutu Patrystycznego w Tarnowie. Nie wiemy, jakie były tego bezpośrednie powody. Być może brak dostatecznej miejscowej patrystycznej kadry profesorskiej lub względy finansowe, a może świadomość, że w tej stworzonej przez siebie instytucji sam niewiele miałby do powiedzenia poza obowiązkiem jej utrzymywania. O Instytucie Patrystycznym w Tarnowie powoli zapominano. Wspomniał o nim jeszcze papież Jan Paweł II w swoim przemówieniu do profesorów Papieskiego Wydziału Teologicznego (9 VI 1979 r.) podczas swej I pielgrzymki do Ojczyzny ${ }^{6}$. W gmachu Wyższego Seminarium Duchownego istniał jeszcze przez jakiś czas (w sali 50) zorganizowany w międzyczasie piękny wyłożony drewnem Zakład Patrystyczny (Patristicum), w którym zgromadzono na regałach wyselekcjonowane z ogólnej biblioteki seminaryjnej wszystkie książki patrystyczne, uzupełnione 752 nowymi zakupionymi w tym czasie pozycjami (m.in. 164 tomy „Sources Chrétiennes”, 17 tomów „Corpus Christianorum”, 14 uzupełniających tomów Migne’a, 58 tomów „Théologie historique”, 17 tomów „Studia Patristica”, 35 tomów „Studi e Testi”, z czasopism: „Augustinianum”, ,,Vetera Christianorum”, Vigiliae Christianae” „Rivista di Archeologia Christiana”, „Bulletin de Littérature Ecclésiastique”, „Bulletin de Théologie Ancienne et Medievale”, ,Revue d'Histoire Ecclésiastique”, ,Church History”, ,Journal of Theological Studies”), ale i ten wkrótce zlikwidowano, a książki przeniesiono do ogólnej biblioteki seminaryjnej. Tarnowski Instytut Patrystyczny przechodził do wspomnień. Niech te kilka uwag o tej ciekawej i niewątpliwie godnej zauważenia inicjatywie w historii polskich studiów nad antykiem chrześcijańskim, przyczynią się, by ją uchronić od całkowitego zapomnienia.

${ }^{6}$ Por. Pielgrzymka Jana Pawła II do Polski. Przemówienia - dokumentacja, Poznań-Warszawa 1979, s. 186: „Wydział zgodnie ze swoim charakterem i statutem prowadził i prowadzi nadal również studia w zakresie tak zwanego cyclus specialisationis, przygotowujące do licencjatu i doktoratu. Studia te prowadzone są przede wszystkim w Krakowie. Prócz tego jednak została już zawarta umowa z Ordynariuszem Tarnowskim o powołaniu specjalistycznego Instytutu Patrologii w Tarnowie. Specjalistyczny też profil posiada wcześniej uzgodniony z Ordynariuszem Częstochowskim Instytut Eklezjologiczno-Mariologiczny w Częstochowie. Jeszcze też za mojego urzędowania została wdrożona sprawa Instytutu Pastoralnego w Katowicach”. 


\title{
DE INSTITUTO PATRISTICO TARNOVIAE ERIGENDO
}

\author{
(Argumentum)
}

Hac in dissertatiuncula agitur de Instituto Patristico quod episcopus Tarnoviensis J.Ablewicz annis 1977-1979 inspirante cardinale K.Wojtyła Tarnoviae uti partem specialisandi in scientiis patristicis Pontificiae Facultatis Theologicae Cracoviensis fundare tentabat. Post introductionem, in qua circumstantiae huiusmodi erectionis exponuntur, documenta id est: Statuta futuri Instituti, Programma studiorum, Collegium professorum, quae de hac re in Congregationem pro Educatione Catholica missa sunt necnon Responsio eiusdem Congregationis adducuntur. 